\title{
Author Correction: Landscape of multi-nucleotide variants in 125,748 human exomes and 15,708 genomes
}

Qingbo Wang (B), Emma Pierce-Hoffman, Beryl B. Cummings, Jessica Alföldi B, Laurent C. Francioli@i, Laura D. Gauthier, Andrew J. Hill, Anne H. O’Donnell-Luria (D), Genome Aggregation Database Production Team, Genome Aggregation Database Consortium, Konrad J. Karczewski (i) \& Daniel G. MacArthur (1)

Correction to: Nature Communications https://doi.org/10.1038/s41467-019-12438-5, published online 27 May 2020.

The original version of this Article omitted from the Genome Aggregation Database consortium the member Marquis P. Vawter, from the Department of Psychiatry \& Human Behavior, University of California Irvine, Irvine, CA, USA. Additionally, the following was added to the Author Contributions: 'All authors listed under The Genome Aggregation Database Consortium contributed to the generation of the primary data incorporated into the gnom $\mathrm{AD}$ resource'.

This has been corrected in both the PDF and HTML versions of the Article.

Published online: 02 February 2021

(c) Open Access This article is licensed under a Creative Commons Attribution 4.0 International License, which permits use, sharing, adaptation, distribution and reproduction in any medium or format, as long as you give appropriate credit to the original author(s) and the source, provide a link to the Creative Commons license, and indicate if changes were made. The images or other third party material in this article are included in the article's Creative Commons license, unless indicated otherwise in a credit line to the material. If material is not included in the article's Creative Commons license and your intended use is not permitted by statutory regulation or exceeds the permitted use, you will need to obtain permission directly from the copyright holder. To view a copy of this license, visit http://creativecommons.org/licenses/by/4.0/.

(c) The Author(s) 2021 